\title{
THE EFFECT OF CYPROTERONE ACETATE ON THE DURATION OF PREGNANCY AND PARTURITION IN MICE
}

\author{
F. ELLENDORFF, H. F. RÖVER AND D. SMIDT \\ Section of Reproductive Biology, Department of Animal Science, \\ University of Göttingen, Albrecht-Thaerweg 1, 3400 Göttingen, Germany
}

(Received 16th August 1972)

\begin{abstract}
Summary. The effect of cyproterone acetate on the duration of pregnancy and the number of embryos (normal, hypertrophied or degenerated) was investigated. Pregnant NMRI-strain albino mice were injected on Days 1 to 10 , or Days 10 to 15 with either 0.5 or $5.0 \mathrm{mg}$ cyproterone acetate (CA) or the vehicle (V). In the CA-treated animals, no parturitions occurred up to Day 21 of pregnancy. The number of offspring did, in general, not differ between the CA-treated animals and the controls. The number of normal offspring was less and the number of abnormal embryos was larger in the CA-treated animals compared with the controls. Hormonal induction of parturition showed positive results after oestrogen-oxytocin administration. The effect of CA was attributed (a) to its progestational activities, and (b) to possible direct effects on the development of the embryos.
\end{abstract}

Cyproterone acetate $(\mathrm{CA})$ has aroused much interest due to its antiandrogenic properties (Neumann, von Berswordt-Wallrabe, Elger, Steinbeck, Hahn \& Kramer, 1970), its ability to modify fetal sexual differentiation when administered during gestation (Neumann, Richter \& Günzel, 1965; Elger, 1966; Neumann et al., 1970) and its ability to sustain strong progestational activities (Wiechert, Steinbeck, Elger \& Neumann, 1967). A blockade of parturition was reported by Neumann et al. (1965) in the rat, where even high doses of oxytocin were not able to overcome it. Our experiments on CA were conducted in the mouse and were designed to obtain quantitative information on: (1) the degree to which parturition is blocked; (2) the number, and condition of the offspring; (3) the possibility of overcoming the block to parturition.

Our experiments were conducted on virgin NMRI-strain albino mice (NMRI/HAN, Zentralstelle für Versuchstierkunde, Hannover, Germany) which weighed initially between 22.5 and $33.0 \mathrm{~g}$. The animals were maintained under constant conditions $\left(22^{\circ} \mathrm{C} \pm 2 ; 60\right.$ to $65 \%$ relative humidity; $10 \mathrm{hr}$ lightfrom 08.00 to 18.00 hours; free access to standard mice pellets and water). Five females were kept in a cage with a male of established fertility. The day on which vaginal plugs were found was designated Day 1 of pregnancy and of the experiment. The experimental groups were as follows: (1) Controls-which 
received no treatment; (2) Group V1-which received $0.05 \mathrm{ml}$ of the vehicle, i.e. $40 \%$ benzyl benzoate and $60 \%$ castor oil, on Days 1 to 10 ; (3) Group V2which received the vehicle on Days 10 to 15 ; (4) Group CA 1-which received $0.5 \mathrm{mg} \mathrm{CA}$ on Days 1 to 10 ; (5) Group CA 2-which received $0.5 \mathrm{mg}$ CA on Days 10 to 15; (6) Group CA 3-which received $5 \mathrm{mg}$ CA on Days 1 to 10; (7) Group CA 4-which received $5 \mathrm{mg} \mathrm{CA}$ on Days 10 to 15 . All injections were given intramuscularly between 10.00 and 12.00 hours. Normal parturition occurred without interference from the experimenter. On Day 21, the number of embryos was counted at autopsy. Where parturition had not occurred, a dead embryo that was not deformed was considered normal as death could have resulted from anaesthesia. Hypertrophied embryos had accumulated large amounts of fluid and were greenish-blue in colour. Degenerated embryos were either not fully developed or clearly atrophic. In several cases, hormones or combinations thereof were administered to CA-treated animals between Days 18 and 25 of pregnancy. For this, Progynon (Schering A. G., Berlin) was injected as 1 to $28 \mathrm{mg}$ oestradiol valerianate with 0.03 to $4 \mathrm{ml}$ oxytocin (10

Table 1. Effect of cyproterone acetate on the duration of pregnancy in mice

\begin{tabular}{l|r|cc}
\hline \multicolumn{1}{c|}{ Treatment } & $\begin{array}{c}\text { No. of } \\
\text { pregnant } \\
\text { mice }\end{array}$ & Mean duration of pregnancy \\
& Days & S.D. \\
\hline Control $0.05 \mathrm{ml}$, Day 1 to 10 & 14 & 20.14 & 0.17 \\
Vehicle 0.0 & 11 & 20.45 & 0.45 \\
Cyproterone acetate 0.5 mg, Day 1 to 10 & 12 & $<21.00$ & - \\
Cyproterone acetate 5 mg, Day 1 to 10 & 9 & $<21.00$ & - \\
\hline Vehicle 0.05 ml, Day 10 to 15 & 14 & 19.64 & 0.33 \\
Cyproterone acetate 0.5 mg, Day 10 to 15 & 17 & $<21.00$ & - \\
Cyproterone acetate 5 mg, Day 10 to 15 & 5 & $<21.00$ & - \\
\hline
\end{tabular}

V.U.-Voegtlin Units-synthetic oxytocin/ml; Impfstoffwerk Friesoythe GMBH, Friesoythe). Statistical analysis involved calculation of the standard deviations and testing for significance with Student's $t$ test.

Pregnancy in CA-treated mice was prolonged by both dosages and time sequences (Table 1). No parturition occurred in these groups before Day 21. The $t$ test revealed no significant differences between the control and vehicletreated animals. The influence of CA on the litter size and condition of the embryo during the first and second half of pregnancy is shown in Text-fig. 1. The total number of embryos was not affected except in one case. Animals of Group CA 4 were carrying significantly fewer embryos than any other group $(P<0.05)$. The mice in Group CA 2 also had fewer normal than abnormal offspring, though this did not reach significant levels. Compared with those found in control mice, a significant increase $(P<0.05)$ in the number of hypertrophied embryos was found in the mice of Group CA 1 and in those of Group CA 4. A non-significant increase occurred also in the Group CA 2 and CA 3 mice. All CA-treated groups, except those of CA 4 , had significantly higher $(P<0.001)$ numbers of degenerated fetuses than the controls. 
Attempts to induce labour or parturition were successful only in mice receiving $0.5 \mathrm{mg} \mathrm{CA}$ and only in five of twenty-nine cases. Labour occurred in one mouse primed with excessive doses of oestradiol valerianate and successively injected with very high doses of oxytocin (40 V.U. twice within $2 \mathrm{hr}$ ) and also in two mice primed with $40 \mathrm{mg}$ oestradiol valerianate and 3 V.U. oxytocin. Finally, parturition occurred in one mouse which was given $16.0 \mathrm{mg}$ oestradiol valerianate and 10 V.U. oxytocin at the same time, and in one out of five mice given $16.0 \mathrm{mg}$ oestradiol valerianate and $10 \mathrm{~V} . \mathrm{U}$. oxytocin at the same time, and $2 \mathrm{hr}$ later. All fetuses had degenerated.

Pregnancy may be maintained by progesterone treatment of ovariectomized rats (Kroc, Steinetz \& Beach, 1959) and may be prolonged after such treatment in the intact or ovariectomized mouse (Bloch, 1957a, b; Kroc et al., 1959). It has been established that CA possesses high progestational activities (Wiechert $e t$ al., 1967), and the prolonged gestation periods recorded in this experiment after CA treatment may have been due to its progestational properties. This view is

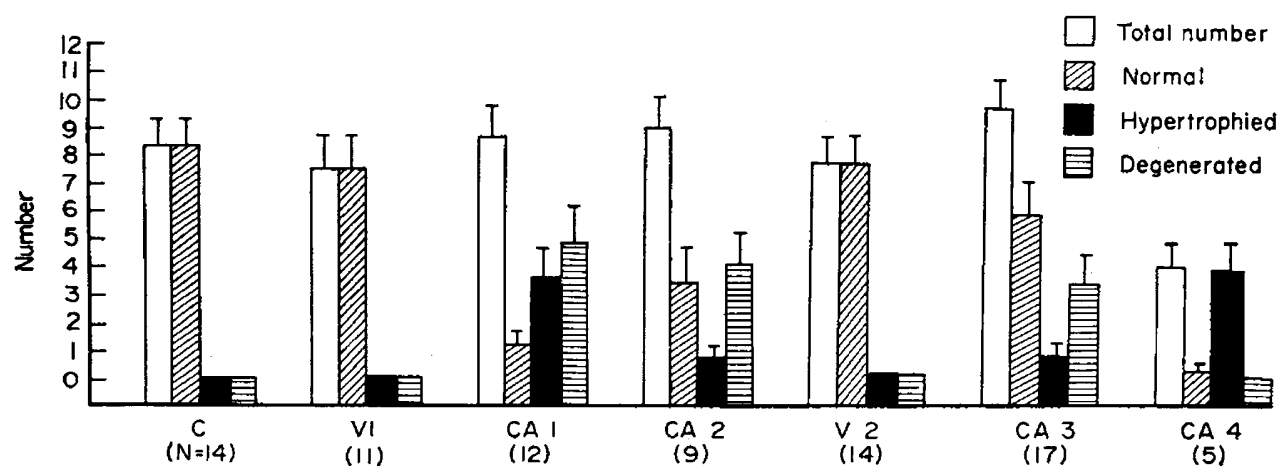

TExT-Fig. 1. Cyproterone acetate administered to mice during the first or second half of pregnancy: effects on the numbers of normal and deformed embryos. For treatment of mice in groups $\mathrm{C}, \mathrm{V}$ and $\mathrm{CA}$, see text.

shared by Neumann et al. (1965) who suggested such an explanation in the case of the rat. Our data prove that CA exerts the same effect in the mouse. Since parturition did not occur although injections were terminated at mid-pregnancy in some groups, it seems probable that CA retains its progestational properties over a period of several days.

The total number of embryos was not affected by the various treatments except in those mice in Group CA 4 which had significantly fewer embryos. The progestational substance applied in our experiments may have had a protective effect on the embryos. The adverse effects of the treatment in Group CA 4 may have been due to a direct and possibly toxic effect on the embryos. The results obtained from further subdividing the embryos into normal, hypertrophied and degenerated support this assumption since, during the second half of pregnancy, only higher dosages of CA decreased the number of normal offspring significantly.

In the early phase of pregnancy, CA did not seem to interfere adversely with 
the process of implantation. The number of embryos in groups of mice treated early in pregnancy did not differ significantly from those in the controls. The implantation process had already been completed by the time the second time sequence of hormone treatment was started. However, relatively large numbers of embryos in the groups treated early in pregnancy and in the groups receiving low dosages in late pregnancy had degenerated. These results suggest that CA retards the development of the embryos and death may occur at a stage too late for complete resorption of the embryos. While no degenerated embryos were found in the mice in Group CA 4, the total number of embryos was significantly less than in the controls. This difference is assumed to be due to death occurring after high doses of CA. Since the mice in Group CA 3 did not show this phenomenon, we suggest that the mouse embryo may be especially susceptible to high doses of CA between Days 10 and 15 of pregnancy. Embryonic death is presumed to occur soon after the beginning of the injections since this would allow time for the complete degeneration which was recorded. The occurrence of hypertrophied fetuses is probably due to the prolongation of pregnancy rather than to any specific effect of CA since the fetuses in animals which were examined shortly before parturition was due to take place did not show any such hypertrophy.

Neumann et al. (1965) tried to induce parturition in CA-treated rats by the administration of large doses of oxytocin. These experiments failed, since induction of parturition is known to be dependent on several other parameters such as the changes in progesterone and oestrogen (Kroc et al., 1959) and the concentration of relaxin in the mouse (Hall, 1955; Kroc et al., 1959). The results of the present study suggest that it is oestrogen that is lacking for normal parturition to occur in CA-treated animals. The failure to induce parturition in mice treated with $5 \mathrm{mg}$ CA further supports our assumption that the high dose of CA could have exerted additional negative effects on the organism. Further studies on the timing of hormone administration and dosage level may lead to a higher rate of induction of parturition.

This project was supported by the Deutsche Forschungsgemeinschaft. The authors gratefully acknowledge the skills of Mrs H. Zeddies, Miss M. Kosswig, Mrs F. Smith and Mrs B. Backhaus. Dr F. Neumann, Schering A.G., Berlin, generously supplied cyproterone acetate.

\section{REFERENCES}

BLOCH, S. (1957a) Untersuchungen zur hormonalen Hemmung des Geburtseintritts bei der Maus. Gynaecologia, 143, 426.

BLOCH, S. (1957b) Weitere Untersuchungen über die hormonalen Grundlagen der Nidation. Gynaecologia, 148, 157.

ELGER, W. (1966) Die Rolle der fetalen Androgene in der Sexualdifferenzierung des Kaninchens und ihre Abgrenzung gegen andere hormonale und somatische Faktoren durch Anwendungeines starken Antiandrogens. Dissertation, University of Berlin.

HALL, K. (1955) The effect of various combinations of progesterone and oestrogen on the symphysis pubis of ovariectomized mice. 7. Endocr. 12, 247.

Kroc, R. L., Steinetz, B. G. \& BEAch, V. L. (1959) The effect of estrogens, progestagens and relaxin in pregnant and nonpregnant laboratory rodents. Ann. N.Y. Acad. Sci. 75, 942. 
Neumann, F., Richter, K. D. \& Günzel, P. (1965) Wirkungen von Antiandrogenen. Zentbl. VetMed. (A), 12, 171.

Neumann, F., von Berswordt-Wallrabe, R., Elger, W., Steinbeck, H., Hahn, J. D. \& Kramer, M. (1970) Aspects of androgen-dependent events as studied by antiandrogens. Recent Prog. Horm. Res. 26, 337.

Wiechert, V. R., Steinbeck, H., Elger, W. \& Neumani, F. (1967) Wirkungen und Struktur neuer Antiandrogener Steroide. Arzneimittel-Forsch. 17, 1103. 